\title{
CRP in Patients with Acute Ischemic Stroke in Bangladesh
}

\author{
MD ROBED AMIN, ${ }^{1}$ HANIF MOHAMMAD, ${ }^{2}$ KAZI GIAS UDDIN AHMED, ${ }^{3}$ DEVENDRA NATH SARKAR ${ }^{4}$
}

\begin{abstract}
:
Objectives: This aim of the study was to evaluate CRP and the risk factors in ischaemic stroke.

Methods: This case control study was carried out from January 2006 to December 2007 in the department of Neurology, Bangabandhu Sheikh Mujib Medical University (BSMMU), Dhaka in all the OPD and admitted stroke patients meeting the inclusion and exclusion criteria.

Results: Out of 30 patients with ischaemic stroke 28(93.3\%) patients had positive C-reactive protein value. 37\% stroke patients were smoker. Mean total cholesterol, triglyceride and LDL level were higher and mean HDL level was lower among stroke patients in comparison to controls. $17 \%$ of stroke patients were suffering from diabetes mellitus $\& 80 \%$ of stroke patients were hypertensive.

Conclusion: C-reactive protein is elevated in the acute phase of ischa emic stroke and could present a prognostic marker.

Key words: CRP, acute ischaemic stroke
\end{abstract}

\section{Introduction}

Stroke is the commonest neurological disorder of adult life and remains third leading cause of death after heart disease and cancer, after the age of $40 .{ }^{1}$ Of the hundreds of thousands of stroke survivors each year, approximately 30 percent require assistance for activities of daily living, 20 percent require assistance with ambulation and 16 percent require institutional care. ${ }^{2}$

In general, its incidence is 150 to 300 per 100,000 populations and prevalence is $600 / 100,000$ population. Of all strokes, 85 percent are due to ischaemic infarction and 15 percent are due to haemorrhage. The highest incidence of stroke seen is 7/1000 at Novosibriska, Russia, and lowest is $2.4 / 1000$ at Dijon, France. ${ }^{3}$ In Bangladesh the incidence of stroke is 700,000 per year. Stroke causing about 4 million deaths per year) and is the most important single cause of severe disability in people living in their own home. ${ }^{4}$

There are many risk factors of stroke. Among them, some are non-modifiable, like age, sex, race, etc. and some are modifiable like hypertension, diabetes mellitus, ischaemic heart disease(IHD), valvular heart disease, smoking, dyslipidaemia, asymptomatic carotid bruit/stenosis, aortic arch atheromatosis, etc. ${ }^{5}$

C-reactive protein (CRP), one of the acute-phase reactants, is an indicator of underlying systemic inflammation and a

1. Assistant Prof of Medicine, Dhaka Medical College

2. Senior Consultant, Meedicine, 200 beded Hospital, Narayongonj

3. Junior Consultant, Medicine, 200 beded Hospital, Narayongonj

4. Associate Prof of Medicine, Rangpur Medical College

Correspondence: Dr .Md. Robed Amin, Assistant Professor of Medicine, Dhaka Medical College, Dhaka, Bangladesh.Apt-C-2 House no-76, Block-F, Road- 5, Banani Dhaka, Bangladesh. e.mail: robedamin@yahoo.com novel plasma marker of atherothrombotic disease. ${ }^{6}$ Furthermore, elevated plasma levels of C-reactive protein are not disease specific but are sensitive markers produced in response to tissue injury, infectious agents, immunologic stimuli, and inflammation. ${ }^{7}$ Elevated blood levels of Creactive protein (CRP) are associated with an increased risk of atherosclerotic vascular disease including stroke. ${ }^{8}$ However the role of CRP in the etiology and prognosis of ischemic stroke remains to be clearly defined. ${ }^{9}$ One hypothesis is that CRP plays a direct causal role in the pathogenesis of atherosclerosis by promoting endothelial cell adhesion molecule expression, monocyte recruitment or complement activation, or by mediating low density lipoprotein cholesterol uptake by macrophages. ${ }^{10}$

Elevated blood concentrations of CRP during the acute phase of ischemic stroke event primarily reflect the extent of cerebral ischemic injury and its complications. ${ }^{11}$ Higher values of C-reactive protein (CRP) are significantly associated with large infarct size and worst outcome. ${ }^{12}$ Use of plasma CRP levels may aid in identifying a potentially large number of men and women who are at risk for cerebrovascular events. ${ }^{7}$ The purpose of this study is To evaluate $\mathrm{C}$-reactive protein in patients with acute ischaemic stroke, To evaluate the risk factors in ischaemic stroke and To observe the elevation of C-reactive protein in patients with acute ischaemic stroke.

\section{Materials and Methods}

This was a case control study which was carried out in the department of Neurology in collaboration with the department of Microbiology and Immunology, Bangabandhu Sheikh Mujib Medical University (BSMMU), Dhaka. The study was done from January 2006 to December 2007 in all the patients with stroke attending the outpatient department (OPD) and also admitted into the indoor of the neurology department, meeting the inclusion and exclusion criteria, were 
included in the study. Patient of more than 30 yrs age and presented with a acute ischaemic stroke ( $<4$ weeks duration) proved clinically and by neuroimaging (CT/MRI of brain) were defined as case and Apparently healthy and age and sex matched with the case were control. Age below 30 years, Hemorrhagic stroke proved by neuroimaging, history of acute myocardial infarction, venous thrombosis, and myeloproliferative diseases, history of rheumatological and connective tissue diseases, history of malignancy,History of recent surgery (within one month) and history of recent infection (within one month) were excluded from the study.

After taking the detail history and physical examination a total 73 patients were included for neuroimaging (CT Scan/ MRI of brain) study. Among them 23 patients were excluded due to the evidence of hemorrhage in neuroimaging. Among the remaining 50 patients 20 patients were excluded from the study group due to the evidence of infection, rheumatological disorder and history of acute myocardial infarction. Ultimately a total of 30 patients were included in the study group whom met the inclusion and exclusion criteria. Out of 30 patients CT scan of brain was done in 25 patients and MRI of brain was done in 5 patients.

Detail history was taken about age, hypertension, diabetes, smoking habit, cardiac disease and oral contraceptive pills. They were also asked about febrile infection or productive cough, diarrhoea and dysuria. They were clinically evaluated for the presence of sinusitis, diabetes, hypertension, and tuberculosis, pneumonia, bronchitis. For detection of lymphadenopathy cervical, supraclavicular, axillary and inguinal groups of lymph nodes were searched for. They were also clinically evaluated for presence of any valvular and ischemic heart disease.

All of them were investigated for serum C-reactive protein, complete blood count, serum creatinine, random blood sugar RBS, serum lipid profile, ECG and chest X-ray PA view. Written consent was taken from the patient or relatives after explaining the study procedure and aims of the study A total of 30 age and sex matched and apparently healthy persons were taken as controls. Controls never suffered from stroke and came in neurology out patient department for nonspecific disorders and symptoms like anxiety neurosis, myalgia, burning limbs, tingling numbness, headache and somatoform disorders and had no clinically apparent infection or inflammation or sign of neurological deficit. All the obtained data were recorded in a pre-structured case record form.

C-reactive protein in serum was estimated by Nephelometric System by using commercial kit (DADE BEHRING BN 100, USA) in the department of Microbiology and Immunology of Bangabandhu Sheikh Mujib Medical University. Under aseptic precaution $5 \mathrm{ml}$ of random venous blood was collected in a test tube. It was kept for 5-10 minutes for clotting. It was then centrifuged at the rate of 5,000-10,000 rpm for 10 minutes.
In this way serum was separated. $200 \mu 1$ serum was taken into sample cup. Then reagent was taken into predefined reagent cup. The Behring Nephelometer 100 analyzer took reaction buffer, diluent, distilled water automatically. Quantitative measurement of C-reactive protein was estimated from the serum following automated analyzer program directed in computer. C-reactive protein level was expressed in $\mathrm{mg} / \mathrm{L}$.

Random blood sugar was also estimated by kit method in Biochemistry department of BSMMU.Fasting lipid profile was also estimated by kit method in Biochemistry department of BSMMU.Total count of WBC, differential count of WBC, $\mathrm{Hb} \%$ and ESR was done in clinical pathology department of BSMMU.Urine routine and microscopic examination were done in clinical pathology department of BSMMU to exclude urinary tract infection. X-ray chest $\mathrm{P} / \mathrm{A}$ view was done in Radiology and imaging Department of BSMMU. Neuroimaging (CT Scan of brain/MRI of brain) was done in Radiology and Imaging department of BSMMU and also from some private diagnostic centers.Electrocardiogram [ECG]-A 12 lead standard ECG was done in the department of Cardiology of BSMMU.

Blood pressure was measured by Mercury Sphygmomanometer. It was measured from the mid-arm of the left side in lying position.

Data analysis was done by Computer based software; statistical package for social sciences (SPSS) was used to analyze collected data. Appropriate analysis, such as Unpaired Student's ' $t$ ' test, Chi-square test, Z-test, etc, were carried out. $\mathrm{P}$ value $<0.05$ was taken as minimum level of significance.

\section{Results}

This was a case control study carried out to evaluate the serum $\mathrm{C}$ reactive protein in patients with acute ischaemic stroke. A total 30 patients diagnosed as ischaemic stroke clinically and confirmed by neuroimaging were evaluated. Age and sex matched apparently healthy person of same number were also taken as control. Majority (63\%) of study subjects were in between 51 to 80 years of age.

Table-I

Age distribution of the study subjects

\begin{tabular}{lccc}
\hline Age (years) & $\begin{array}{c}\text { Case }(\mathrm{n}=30) \\
\text { No. }(\%)\end{array}$ & $\begin{array}{c}\text { Control }(\mathrm{n}=30) \\
\text { No. }(\%)\end{array}$ & P value \\
\hline$<40$ & $7(23.3)$ & $3(10.0)$ & \\
4150 & $4(13.3)$ & $11(36.7)$ & \\
5160 & $6(20.0)$ & $10(33.3)$ & $>0.05^{\text {ns }}$ \\
6170 & $10(33.3)$ & $5(16.7)$ & \\
7180 & $3(10.0)$ & $1(3.3)$ & \\
Range & 3580 & 3271 & \\
Mean \pm SD & $56.30 \pm 13.70$ & $53.43 \pm 9.94$ & $>0.10^{\text {ns }}$ \\
\hline
\end{tabular}

Chi square test/Unpaired Student's ' $t$ ' test ns $=$ Not significant 
The study showed $21(70 \%)$ patients were male and $9(30 \%)$ patients were female. Among control 25(83.3\%) were male and $5(16.7 \%)$ were female.

It was found $28(93.3 \%)$ patients had positive C-reactive protein value and only $2(6.7 \%)$ patients had negative $\mathrm{C}$ reactive protein value. Among control group all had negative $\mathrm{C}$-reactive protein value.

\section{Table II}

Study of risk factors among the study subjects

\begin{tabular}{|c|c|c|c|c|c|}
\hline Parameters & $\begin{array}{c}\text { Case } \\
(n=30) \\
\text { No. }(\%)\end{array}$ & $\begin{array}{c}\text { Control } \\
(n=30) \\
\text { No. }(\%)\end{array}$ & $\begin{array}{l}\mathrm{P} \\
\text { value }\end{array}$ & $\begin{array}{l}\text { Odds } \\
\text { ratio }\end{array}$ & $\begin{array}{c}95 \% \\
\text { CI }\end{array}$ \\
\hline \multicolumn{2}{|c|}{ Smoking habit } & & $>0.50^{\mathrm{ns}}$ & 1.351 & $0.460-3.968$ \\
\hline Yes & $11(36.7)$ & $9(30.0)$ & & & \\
\hline No & $19(63.3)$ & $21(70.0)$ & & & \\
\hline \multicolumn{2}{|c|}{ Hypertension } & & $<0.001^{* * *}$ & \multicolumn{2}{|c|}{$20.0005 .384-74.298$} \\
\hline Yes & $24(80.0)$ & $5(16.7)$ & & & \\
\hline No & $6(20.0)$ & $25(83.3)$ & & & \\
\hline \multicolumn{2}{|l|}{ Diabetes } & & $<0.05^{*}$ & 2.200 & $1.647-2.939$ \\
\hline Yes & $5(16.7)$ & 0 & & & \\
\hline No & $25(83.3)$ & $30(100.0)$ & & & \\
\hline \multicolumn{2}{|c|}{ Cardiac disease } & & $>0.10^{\mathrm{ns}}$ & 2.034 & $1.569-2.637$ \\
\hline Yes & $1(3.3)$ & 0 & & & \\
\hline No & $29(96.7)$ & $30(100.0)$ & & & \\
\hline \multicolumn{4}{|c|}{ Oral contraceptives (female only) $>0.10^{\mathrm{ns}}$} & 1.833 & $1.069-3.144$ \\
\hline Yes & $3(33.3)$ & 0 & & & \\
\hline No & $6(66.7)$ & $5(100.0)$ & & & \\
\hline
\end{tabular}

Chi square test, $\mathrm{ns}=$ Not significant, $* / * * *=$ Significant

The study shows prevalence of risk factors among cases and control subjects. (table-II) Present smoker and who stopped smoking for less than 6 months was considered as smoker. In case group $11(36.6 \%)$ were smokers compared to $9(30 \%)$ in control group ( $\mathrm{p}$ value $>0.50)$. Hypertension was significantly $(\mathrm{p}<0.001)$ distributed between case group $(80.0 \%)$ and control group (16.7\%). Diabetes Mellitus was present in 5 patients $(16.7 \%)$ and none of the control had DM. Three of the 9 female patients $(33.3 \%)$ had the history of taking oral contraceptive pills. One patient $(3.3 \%)$ had history of cardiac disease in the form of IHD.

Mean Systolic Blood Pressure was $152.67(\mathrm{SD} \pm 21.65) \mathrm{mmHg}$ and $127.50 \mathrm{~s}(\mathrm{SD} \pm 8.17) \mathrm{mmHg}$ between cases and control groups respectively(table III). Similarly Mean Diastolic Blood Pressure was 90.17(SD \pm 13.93$) \mathrm{mmHg}$ and 78.83 $(\mathrm{SD} \pm 8.38) \mathrm{mmHg}$ between cases and control groups respectively. This table showing Systolic Blood Pressure and Diastolic Blood Pressure were significantly higher in the case group $(\mathrm{p}<0.001)$.
Table III

General examination findings

\begin{tabular}{lccccc}
\hline Parameters & $\begin{array}{c}\text { Case } \\
(\mathrm{n}=30)\end{array}$ & $\begin{array}{c}\text { Control } \\
(\mathrm{n}=30)\end{array}$ & t value & df & P value \\
\hline Pulse rate $(\mathrm{b} / \mathrm{min})$ & & & & & \\
Mean \pm SD & $81.33 \pm 10.26$ & $76.13 \pm 5.14$ & 2.482 & 58 & $<0.05^{*}$ \\
Range & 68120 & 6888 & & & \\
SBP(mmHg) & & & & & \\
Mean \pm SD & $152.67 \pm 21.65$ & $127.50 \pm 8.17$ & 5.958 & 58 & $<0.001^{* * *}$ \\
Range & 100190 & 120150 & & & \\
DBP(mmHg) & & & & & \\
Mean \pm SD $90.17 \pm 13.93$ & $78.83 \pm 8.38$ & 3.820 & 58 & $<0.001^{* * *}$ \\
Range & 40110 & 70100 & & & \\
\hline
\end{tabular}

Unpaired Student's ' $\mathrm{t}$ ' test

$* / * * *=$ Significant

Total count of WBC was higher in case group along with neutrophilic leucocytosis $(\mathrm{p}<0.001)$. ESR was a bit higher in case group, $12.40(\mathrm{SD} \pm 4.88)$ vs. 9.77( $\mathrm{SD} \pm 2.65)(\mathrm{p}<0.05)$. Serum Creatinine was within normal limit.(table IV)

Table IV

Investigation results

\begin{tabular}{|c|c|c|c|c|c|}
\hline Parameters & $\begin{array}{c}\text { Case } \\
(\mathrm{n}=30)\end{array}$ & $\begin{array}{l}\text { Control } \\
(n=30)\end{array}$ & t value & $\mathrm{df}$ & P value \\
\hline \multicolumn{6}{|l|}{$\overline{\mathrm{Hb}(\mathrm{g} / \mathrm{dl})}$} \\
\hline Range & $9.80-16.00$ & $10.00-15.00$ & & & \\
\hline Mean \pm SD & $11.58 \pm 1.69$ & $11.94 \pm 1.30$ & 0.917 & 58 & $>0.10^{\mathrm{ns}}$ \\
\hline \multicolumn{6}{|c|}{ Total count $(\mathrm{cmm})$} \\
\hline Range & $8000-14500$ & $7000-11000$ & & & \\
\hline Mean \pm SD & 11363.33 & $\begin{array}{c}9650.00 \\
\pm 1596.65\end{array}$ & $\begin{array}{c}4.953 \\
\pm 1020.40\end{array}$ & 58 & $<0.001^{* * *}$ \\
\hline \multicolumn{6}{|c|}{ Differential count $(\%)$} \\
\hline Range & $55-84$ & $58-80$ & & & \\
\hline Mean \pm SD & $75.33 \pm 6.02$ & $68.13 \pm 4.86$ & 5.097 & 58 & $<0.001^{* * *}$ \\
\hline \multicolumn{6}{|l|}{ Lymphocyte } \\
\hline $\begin{array}{l}\text { Range } \\
\text { Mean } \pm \text { SD }\end{array}$ & $\begin{array}{c}12-35 \\
18.63 \pm 4.98\end{array}$ & $\begin{array}{c}15-32 \\
23.63 \pm 3.90\end{array}$ & 4.330 & 58 & $<0.001^{* * *}$ \\
\hline \multicolumn{6}{|l|}{ Monocyte } \\
\hline $\begin{array}{l}\text { Range } \\
\text { Mean } \pm \text { SD }\end{array}$ & $\begin{array}{c}1-6 \\
3.57 \pm 1.63\end{array}$ & $\begin{array}{c}2-6 \\
4.43 \pm 1.22\end{array}$ & 2.326 & 58 & $<0.05^{*}$ \\
\hline \multicolumn{6}{|l|}{ Eosinophil } \\
\hline Range & $1-4$ & $2-6$ & & & \\
\hline Mean \pm SD & $2.80 \pm 0.92$ & $3.80 \pm 0.85$ & 4.368 & 58 & $<0.001^{* * *}$ \\
\hline \multicolumn{6}{|c|}{$\operatorname{ESR}(\mathrm{mm} / 1 \mathrm{st} \mathrm{hr})$} \\
\hline Range & $2-20$ & $6-18$ & & & \\
\hline Mean \pm SD & $12.40 \pm 4.88$ & $9.77 \pm 2.65$ & 2.597 & 58 & $<0.05^{*}$ \\
\hline \multicolumn{6}{|c|}{ Serum creatinine $(\mathrm{mmol} / \mathrm{L})$} \\
\hline Range & $78-130$ & $70-110$ & & & \\
\hline Mean \pm SD & $107.70 \pm 8$ & $9684.60 \pm 7.50$ & 10.825 & 58 & $<0.001^{\text {*** }}$ \\
\hline
\end{tabular}

Unpaired Student's ' $\mathrm{t}$ ' test, $\mathrm{ns}=$ Not significant, $* / * * *=$ Significant 
Mean value of C-reactive protein was $42.06 \mathrm{mg} / \mathrm{L}(\mathrm{SD} \pm 21.26)$ vs. 4.30 ( $\mathrm{SD} \pm 0.72$ ) between case and control groups. $(\mathrm{p}<0.001)$. There was no significant effect of risk factors on C-reactive protein level.(table V) and no significant relation to ESR as well

\section{Table V}

Effect of risk factors on $C$-reactive protein

\begin{tabular}{cccccc}
\hline Parameters & $\begin{array}{r}\text { Present } \\
\text { No. (\%) }\end{array}$ & $\begin{array}{c}\text { Absent } \\
\text { No. (\%) }\end{array}$ & $\begin{array}{c}\text { Palue } \\
\text { ratio }\end{array}$ & $\begin{array}{c}\text { Odds } \\
\text { CI }\end{array}$ \\
\hline Smoking habit & \multicolumn{5}{c}{$>0.10^{\text {ns }}$} \\
$\mathrm{n}$ & $11(36.7)$ & $19(63.3)$ & & \\
$\mathrm{CRP}+$ ve & $11(100.0)$ & $17(89.5)$ & 1.118 & $0.958-1.304$ \\
CRP ve & 0 & $2(10.5)$ & &
\end{tabular}

History of hypertension $\quad>0.10^{\mathrm{ns}}$

$$
\begin{array}{lcc}
\mathrm{n} & 24(80.0) & 6(20.0) \\
\mathrm{CRP}+\mathrm{ve} & 23(95.8) & 5(83.3) \\
\mathrm{CRP} \text { ve } & 1(4.2) & 1(16.7)
\end{array}
$$$$
1.150 \quad 0.796-1.661
$$$$
0.250 \quad 0.018-3.446
$$

History of diabetes

$$
>0.50^{\mathrm{ns}}
$$

$$
\begin{array}{lcc}
\mathrm{n} & 5(16.7) & 25(83.3) \\
\mathrm{CRP}+\mathrm{ve} & 5(100.0) & 23(92.0) \\
\mathrm{CRP} \text { ve } & 0 & 2(8.0)
\end{array}
$$

$1.087 \quad 0.968-1.220$

History of cardiac disease

$$
>0.50^{\mathrm{ns}}
$$

$$
\begin{array}{lcc}
\mathrm{n} & 1(3.3) & 29(96.7) \\
\mathrm{CRP}+\mathrm{ve} & 1(100.0) & 27(93.1) \\
\mathrm{CRP} \text { ve } & 0 & 2(6.9)
\end{array}
$$

$1.0740 .973-1.186$

History of OCP (female only) $\quad>0.10^{\text {ns }}$

$$
\begin{array}{lcc}
\mathrm{n} & 3(33.3) & 6(66.7) \\
\mathrm{CRP}+\mathrm{ve} & 3(100.0) & 5(83.3) \\
\mathrm{CRP} \text { ve } & 0 & 1(16.7)
\end{array}
$$

Chi square test, $n s=$ Not significant

$\mathrm{CRP}$ ve $=2, \mathrm{CRP}+\mathrm{ve}=28$ irrespective of $\mathrm{sex}$

$\mathrm{CRP}$ ve $=1, \mathrm{CRP}+\mathrm{ve}=8$ for females

Value of total cholesterol, Triglyceride and LDL level was

\begin{tabular}{|c|c|c|c|c|c|}
\hline & $\mathrm{n}$ & 2 & 30 & & \\
\hline Range & $160-220$ & $260-240$ & & & \\
\hline Mean \pm SD & $190.00 \pm 42.43$ & $196.00 \pm 16.94$ & 0.447 & 30 & $>0.50^{\mathrm{ns}}$ \\
\hline & Pvalue & $>0.10^{\mathrm{ns}}$ & & & \\
\hline
\end{tabular}
higher and HDL was lower among case group. In case group total cholesterol, Triglyceride, LDL and HDL level between $\mathrm{CRP}+\mathrm{ve}$ and $\mathrm{CRP}-\mathrm{ve}$ was not significant. Among control group all are CRP -ve. Comparison of lipid profile between case CRP - ve and control CRP - ve also didn't show any significant difference

\begin{tabular}{|c|c|c|c|c|c|}
\hline & $\mathrm{n}$ & 2 & 30 & & \\
\hline Range & $120-160$ & $100-155$ & & & \\
\hline Mean \pm SD & $140.00 \pm 28.28$ & $128.17 \pm 14.81$ & 1.049 & 30 & $>0.10^{\mathrm{ns}}$ \\
\hline valu & Pvalue & $>0.50^{\mathrm{ns}}$ & & & \\
\hline \multicolumn{6}{|l|}{ HDL (mg/dl) } \\
\hline \multicolumn{6}{|l|}{ CRP +ve } \\
\hline & $\mathrm{n}$ & 28 & 0 & & \\
\hline Range & 4048 & & & & \\
\hline Mean \pm SD & $44.39 \pm 2.42$ & & & & \\
\hline \multicolumn{6}{|l|}{ CRP ve } \\
\hline $\mathrm{n}$ & 2 & 30 & & & \\
\hline Range & 4648 & 4056 & & & \\
\hline Mean \pm SD & $47.00 \pm 1.41$ & $48.57 \pm 4.03$ & 0.540 & 30 & $>0.50^{\mathrm{ns}}$ \\
\hline Pvalue & $>0.10^{\mathrm{ns}}$ & & & & \\
\hline
\end{tabular}

Table-VI

Lipid profile

\begin{tabular}{cccccc}
\hline Parameters & Case & Control & $\mathrm{t}$ & $\mathrm{df}$ & $\mathrm{P}$ \\
& $(\mathrm{Mean} \pm \mathrm{SD})$ & $(\mathrm{Mean} \pm \mathrm{SD})$ & value & & value \\
\hline
\end{tabular}

Total cholesterol (mg/dl)

CRP +ve

$\begin{array}{lc}\mathrm{n} & 28 \\ \text { Range } & 124-260 \\ \text { Mean } \pm \text { SD } & 211.29 \pm 29.31 \\ \text { CRP -ve } & \end{array}$

CRP -ve

Triglyceride (mg/dl)

$\mathrm{CRP}+\mathrm{ve}$

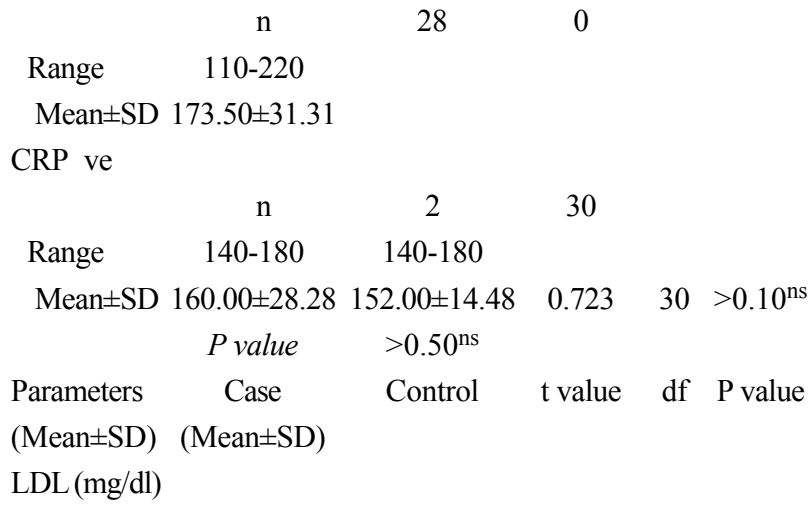

CRP +ve

$\begin{array}{lc} & \mathrm{n} \\ \text { Range } & 110-160 \\ \text { Mean } \pm \text { SD } & 144.43 \pm 12.33 \\ \text { CRP ve } & \end{array}$

Unpaired Student's ' $t$ ' test $\mathrm{ns}=$ Not significant 
Nine patients $(30 \%)$ had enlarged heart in chest X-ray PA view rest are normal(pvalue $<0.001)$. ECG was done in all cases. Fourteen patients $(46.7 \%)$ had nonspecific ST-T changes and $1(3.3 \%)$ patient had atrial fibrillation in ECG.(Table vii)

\section{Table-VII}

ECG finding

\begin{tabular}{lccl}
\hline $\begin{array}{l}\text { Finding } \\
\text { No. }\end{array}$ & $\begin{array}{c}\text { Case }(\mathrm{n}=30) \\
(\%) \text { No. }\end{array}$ & $\begin{array}{c}\text { Control }(\mathrm{n}=30) \\
(\%)\end{array}$ & P value \\
\hline Atrial fibrillation & $1(3.3)$ & 0 & \\
$\begin{array}{l}\text { Nonspecific ST } \\
\text { T change }\end{array}$ & $14(46.7)$ & 0 & $<0.001^{* * *}$ \\
Normal & $15(50.0)$ & 30 & $(100.0)$ \\
\hline
\end{tabular}

Chi square test

$* * *=$ Significant

\section{Discussion}

The present study showed that mean age of the cases was $56.37(\mathrm{SD} \pm 13.73$ ). This finding is consistent with the findings of previous study carried out by Sheuli, 2006 in the Neurology department BSMMU. Similar past studies had comparable age statistics of the patient, for example (Bell et al., 1990) studied 51 stroke patient with majority of (50-69) years; Another study 2001 studied a sample with an average age $58(\mathrm{SD} \pm 12)$ years. $^{13}$

Seventy (70) percent of the study subjects were male. Male to female ratio was 2.33:1. A study in 1995 showed that stroke affects male 1.5 times more often than female ${ }^{14}$. This difference found in the study may be due to the attitude of our society that the females are less frequently brought to the hospitals for treatment.

In this study serum C-reactive protein level was found to be elevated in $28(93.3 \%)$ patients out of 30 . Mean C-reactive protein value was 42.06 ( $\mathrm{SD} \pm 21.26)$ whereas among the control it was $4.30(\mathrm{SD} \pm 0.72)$. These findings are consistent with several studies ${ }^{5,16,17,18}$ The possible explanations are: 1. CRP concentration may reflect the degree of stroke severity, correlating with the degree of inflammation directly consequent to cerebral infarction. 2. CRP concentration may indicate underlying unstable atherosclerotic disease. 3. CRP may be raised as a consequence of secondary complications of stroke at the time of sampling. ${ }^{17}$ We have found 2 stroke patients were negative for C-reactive protein value. Grau, 1997 found about $25 \%$ of patients with first ever ischaemic stroke had normal levels of CRP after stroke. It might be due to the variability of the degree of inflammatory response to ischaemic stroke (Gabay et al., 1999). In 1999 had shown high CRP values in their study compared with much lower levels predictive of cardiovascular morbidity in epidemiological studies that could suggest a vigorous acute phase response rather than a chronic inflammatory low grade response ${ }^{16}$. The inflammatory process represented by CRP elevation could also result from underlying atherosclerotic plaque itself.

The study revealed $37 \%$ stroke patients were smoker. In a study in BSMMU showed 59.84\% smoker among their stroke patients. ${ }^{19}$ This difference may be due to the variation in the number of cases and anti smoking campaign. The contribution of cigarette smoking to an increased risk of stroke is controversial. Although it may have an indirect effect. ${ }^{20}$ One study in 1998 showed an ordered relationship between increasing exposure to cigarette smoke and the prevalence of cerebral infarction. ${ }^{21}$

Eighty (80) percent of stroke patients were hypertensive. Di Napoli et al., 2001 in their study of 1020 stroke patients had shown two third patients were hypertensive. ${ }^{22}$ Sheuli, 2006 found $63.3 \%$ stroke patients were hypertensive in a study.

Senenteen percent of stroke patients were suffering from diabetes mellitus. Ullah et al., 1993 in their study showed $30 \%$ diabetics among stroke patients. Kannel and Wolf, 1983 showed that $10-24 \%$ strokes were attributable to Diabetes. Sheuli ,2006 found 26.7\% had Diabetes Mellitus in her study on ischaemic stroke.

Mean total cholesterol, triglyceride and LDL level were higher and mean HDL level was lower among stroke patients in comparison to controls. This finding is consistent with previous studies (Sheuli,2006). It is already established that exposure of the endothelial surface to risk factors such as hypertension, hyperglycaemia, oxidized low density lipoprotein (LDL) results in endothelial injury that promotes atherosclerosis and its complications.

In this study we have also found that total count of WBC was higher in case group along with neutrophilic leucocytosis. Marquardt et al., 2005 showed in their study that leucocyte count was followed a time course compatible with the pattern of an acute phase reaction showing initial peak and a rapid decline after stroke. Emsley et al., 2003 observed a persistent elevation of leucocyte count along with other factors until 3 months after the event. ESR was found to be a bit higher in the study group but there was no significant relationship between ESR and CRP in case and controls.

The potential role of viral infection in atherogenesis has received much attention in ischaemic heart disease but has 
yet to be found relevant to carotid artery disease. Inflammatory cell infiltration, especially by macrophages has been associated with carotid plaque rupture in a manner analogous to coronary artery disease, and concentration of both circulating and locally synthesized pro inflammatory cytokines are elevated in patients with carotid atherosclerosis. In the majority of patients CRP may therefore be a useful marker of atherosclerotic instability. ${ }^{23}$

In coronary artery disease two recent studies seem to demonstrate that therapy with statins and reducing levels of CRP could reduce progression of atherosclerosis. ${ }^{23,24}$

In cerebrovascular disease the influence of some categories of drugs on atherosclerotic process modifying the acute phase of inflammation was studied. It was suggested that statins and Angiotensin converting enzyme inhibitors could be more effective in the presence of high CRP levels and that the efficacy of anti platelet therapy, such as aspirin or clopidogrel, in secondary prevention could be related to the levels of inflammatory markers. ${ }^{25}$

\section{Limitations of the study}

The study was not prospectively designed to assess the effect of C-reactive protein on outcome of ischaemic stroke. Only a single blood level was checked. The number of cases in this study was small.

\section{Conclusion}

Stroke is actually one of the main problems of health worldwide because of its high incidence, prevalence, mortality, and residual disability. It is of utmost importance to select patients with high risk of negative outcomes and to address them through a most intensive pharmacological and rehabilitative approach. Our study confirms that $\mathrm{C}$-reactive protein is elevated in the acute phase of ischaemic stroke and could present a prognostic marker. Further prospective studies are necessary to demonstrate this hypothesis.

\section{Conflict of Interest : None}

\section{References:}

1. Ropper, A.H. \& Brown, R.H. 2005, 'Cerebrovascular disease', in Adams and Victor's principles of neurology, $8^{\text {th }}$ edn. Mc Graw-Hill company, New York, pp.660-746.

2. Bilter, J. \& Love, B.B. 2004, 'Ischemic cerebrovascular disease', in Neurology in clinical practice, $4^{\text {th }}$ edn, Butterworth Heinemann, Philadelphia, pp.1197-249

3. Sudlow, C.L.M. \& Warlow, C.P. 1997, 'Comparable studies of the incidence of stroke and its pathological types: results form an international collaboration', Stroke, vol.28, pp.491-9.

4. Harris, A.I. 1971, 'Handicapped and impaired in Great Britain', London. Her Majesties Stationary Office.
5. Chesbro, J.H., Fuster, V. \& Halperin, J.L. 1990, 'Atrial fibrillation-risk marker for stroke’, N Eng J Med, vol.323, pp.1556-8.

6. Gabbay, C. \& Kushner, I. 1999, 'Acute phase proteins and other systemic responses to inflammation', N Eng J Med, Vol.340, pp. 448-54.

7. Rost, N.S., Wolf, P.A., Kase, C.S., Kelly, H.M., Silibershatz, H., Massaro, J.M. et al. 2001, 'Plasma concentration of Creactive protein and risk of ischaemic stroke and transient ischaemic attack: The Framingham Study', Stroke, vol.32, pp. 2575-9.

8. Lagrand, W.K., Visser, C.A. \& Hermens, W.T. 1999, 'Creactive protein as a cardiovascular risk factor. More than an epiphenomenonan' Circulation, vol.100, pp.96-102.

9. Yeh, E., Anderson, V. \& Pasari, V. 2001, 'C-reactive protein. Linking inflammation to cardiovascular complications', Circulation, vol.104, pp.974-5.

10. Zwaka, T.P., Hombach, V. \& Torzewski, J. 2001, 'C-reactive protein mediated low density lipoprotein uptake by macrophages. Implications for atherosclerosis', Circulation, vol.103, pp.1194-97.

11. Muir, K.W., Weir, C.J. \& Alwan, W. 1999, 'C-reactive protein and outcome after ischemic stroke', Stroke, vol.30, pp.981-85.

12. Petty, G.W., Brown, R.D. \& Whisnant, J.P. 2000, 'Ischemic stroke subtypes: a population-based study of functional outcome, survival and recurrence', Stroke, vol.31, pp.1062-68.

13. Victor, M. \& Ropper, A.H. 2001, 'Major categories of neurological disease', in Adams and Victor's principles of neurology, $7^{\text {th }}$ edn. McGraw-Hill Companies, New York. pp.655-1292.

14. Cull, R.E. \& Will, R.G. 1995, 'Disease of the nervous system' in Davidson's principles and practice of medicine, $16^{\mathrm{Th}} \mathrm{edn}$, Churchill Livingstone, London, pp.1071-9.

15. Marquardt, L., Ruf, A., Mansmann, U., Winter, R., Buggle, F., Kallenberg, K. et al. 2005, 'C-reactive protein in ischaemic stroke', J Neurol Sci, vol.236, pp.65-71.

16. Keith, W., Cristopher, J., Wafa, A., Lain, B. \& Kennedy, R. 1999, 'C-reactive protein and outcome after ischaemic stroke', Stroke, vol.30, pp.981-5.

17. Hasanuzzaman, M., Ullah, A.K.M.A., Haque, A., Mohammad, Q.D. \& Shahnaz, S. 2004, 'Relationship of protein $\mathrm{C}$ deficiency to ischaemic stroke in young patients' Bangladesh J Neuro Sci, vol.20, pp.16-23.

18. Hsu, K.O., Chung, J., Chia, H., Chen, K. K., Jen, H.C., Farzaneh, S. et al. 2005. 'Relation of C-reactive protein to stroke, cognitive disorders, and depression in the general population: systemic review and meta analysis', Lancet Neurol, vol.4, pp.371-80. 
19. Ullah, A.K.M.A., Hayee, M.A., Rahman, M.H. \& Khandaker, M.A.K. 2002, 'Aetiology of young ischaemic stroke in Bangladesh', Bangladesh J Neuro Sci, vol.18, pp.16-27.

20. Dyken, M.L., Wolf, P.A. \& Barnett, H.J.M. 1984, 'Risk factors in stroke: a statement for physicians by the Subcommittee on Risk Factors and Stroke of the Stroke Council', Stroke, Vol.15, pp.1105-11.

21. Howard, G., Lynne, E.W., Chai, J., Copper, L. \& Kraut, M.A. 1998, 'Cigarette smoking and other risk factors for silent cerebral infarctions in the general population', Stroke, vol.29, pp.913-7.
22. Di, Napoli. M., Papa, F. \& Bocola, V. 2001, 'Prognostic influence of increased C-reactive protein and fibrinogen levels in ischemic stroke', Stroke, vol.32, pp.133-8.

23. Ridker, P.M., Cannon, C.P. \& Morrow, D. 2005, 'C-reactive protein levels and outcome after statin therapy', N Eng J Med, vol.152, pp. 20-8.

24. Nissen, S.E., Tuscu, E.M. \& Schoenhagen, P. 2005, 'Reversal of Atherosclerosis with aggressive lipid lowering (REVERSAL) investigators. Statin therapy, LDL cholesterol, C-reactive protein, and coronary artery disease', N Eng J Med, vol.352, pp.29-38.

25. Masotti, L., Ceccarelli, E., Forconi, S. \& Cappelli, R. 2005, 'Prognostic role of C-reactive protein in very old patients with acute ischaemic stroke', J Int Med, vol.258, pp.145-52. 